\title{
Penyuluhan Kesehatan tentang Pentingnya Deteksi Dini Kanker Payudara dan Praktik Pemeriksaan Payudara Sendiri pada Remaja Putri melalui Zoominar
}

\author{
Shinta Novelia*, Bunga Tiara Carolin \\ Fakultas Ilmu Kesehatan, Universitas Nasional, Jakarta, Indonesia \\ * Correspondent Author: shinta.novelia@civitas.unas.ac.id
}

\begin{abstract}
ABSTRAK
Pemeriksaan payudara sendiri atau SADARI hingga saat ini merupakan cara deteksi dini kanker payudara yang cukup efektif. SADARI mudah dilakukan dan bisa diterapkan kepada semua usia, baik remaja dan wanita dewasa. Dengan melakukan SADARI yang benar dan rutin, sebanyak 80 persen kanker payudara bisa ditemukan. Meski gerakan sangat mudah, nyatanya belum banyak wanita yang tergerak untuk melakukan SADARI. Penyuluhan deteksi dini kanker payudara dengan SADARI dilakukan dengan metode ceramah, demonstrasi dan praktik. Penyuluhan kesehatan terlaksana dengan baik. Sebagian besar peserta mengaku tidak mengerti tentang gejala kanker payudara dan mereka mengakui bahwa kegiatan ini memberikan banyak manfaat bagi mereka.
\end{abstract}

Kata Kunci: SADARI, Kanker Payudara, Deteksi Dini, Remaja Puteri

Received: July 8, 2021

Revised: August 10, 2021

Accepted: September 1, 2021

\section{c) (1) (2)}

This is an open-acces article distributed under the terms of the Creative Commons Attribution-ShareAlike 4.0 International License.

\section{PENDAHULUAN}

Kanker merupakan salah satu jenis penyakit tidak menular yang angka kejadiannya cenderung meningkat pada setiap tahunnya. Data WHO pada tahun 2010 menyebutkan bahwa kanker menempati urutan nomor dua sebagai penyebab kematian terbanyak, berada di bawah penyakit kardiovaskuler (Anggorowati, 2013). Kanker payudara menempati urutan pertama sebagai jenis kanker yang paling umum diderita oleh perempuan di dunia. Kanker payudara memiliki kontribusi sebesar 25\% dari total kasus baru kanker secara keseluruhan yang terdiagnosis pada tahun 2012 (Ferlay et al., 2012). Data Riset Kesehatan Dasar (Riskesdas) pada tahun 2007 menyebutkan bahwa kanker menempati urutan ke tujuh sebagai penyebab kematian terbesar di Indonesia (Depkes RI, 2011). Data Riskesdas 2007 juga menyebutkan bahwa angka nasional kanker adalah 4,3 per 1000 penduduk dengan angka kejadian yang lebih tinggi pada perempuan dari pada laki-laki, yaitu sebesar 5,7 per 1000 penduduk pada perempuan dan 2,9 per 1000 penduduk pada lakilaki (Depkes RI, 2013).

Kanker payudara terjadi akibat adanya keganasan di dalam jaringan payudara. Hal tersebut dapat berasal dari epitel duktus maupun lobulusnya. Kanker payudara memiliki gejalagejala seperti adanya benjolan yang terdapat pada satu atau kedua buah payudara. Benjolan ini merupakan tumor ganas, biasanya memiliki tekstur atau bentuk yang keras dan bentuknya tidak teratur (Angrainy, 2017). 


\section{Journal of Community Engagement in Health}

http://jceh.org

https://doi.org/10.30994/jceh.v4i2.165

ISSN: 2620-3758 (print); 2620-3766 (online)

Vol. 4 No 2. Sep 2021. Page. 282-286

Salah satu upaya untuk meningkatkan melakukan SADARI adalah melalui penyuluhan dengan pelatihan SADARI. Manfaat pemeriksaan payudara sendiri (SADARI) adalah untuk mendeteksi sedini mungkin adanya kelainan pada payudara karena payudara pada hakikatnya dapat diketahui secara dini oleh para wanita usia subur. Setiap wanita mempunyai bentuk dan ukuran payudara yang berbeda, bila wanita memeriksa payudara sendiri secara teratur, setiap bulan setelah haid, wanita dapat merasakan bagaimana payudara wanita yang normal. Bila ada perubahan tentu wanita dapat mengetahuinya dengan mudah (Manuaba, 2010).

Berdasarkan hasil penelitian yang dilakukan oleh Syaiful \& Aristantia (2016) menunjukan bahwa ada perbedaan ketrampilan siswi dalam melakukan pemeriksan SADARI. Sehingga hasil penelitian tersebut dapat disimpulkan bahwa pendidikan kesehatan melalui metode demonstrasi tentang ketrampilan praktik SADARI berpengaruh terhadap ketrampilan praktik SADARI pada siswi SMA.

Penyuluhan kesehatan adalah suatu kegiatan promosi kesehatan berupa pemberian informasi atau pesan kesehatan untuk memberikan atau meningkatkan pengetahuan dan sikap tentang kesehatan agar memudahkan dalam terjadinya perilaku sehat (Ekanita, \& Khosidah, 2013; Ikhwanudin, 2013). Periksa payudara sendiri atau SADARI hingga saat ini merupakan cara deteksi dini kanker payudara yang cukup efektif. SADARI mudah dilakukan dan bisa diterapkan kepada semua usia, baik remaja dan wanita dewasa. Dengan melakukan SADARI yang benar dan rutin, sebanyak 80 persen kanker payudara bisa ditemukan. Meski gerakan sangat mudah, nyatanya belum banyak wanita yang mengetahui dan tergerak untuk melakukan SADARI khususnya remaja putri.

\section{TUJUAN}

Tujuan dari kegiatan pengabdian masyarakat ini adalah :

a. Memberikan pendidikan kesehatan tentang pentingnya deteksi dini kanker payudara

b. Mengetahui tanda dan gejala kanker payudara

c. Mendemokan kegiatan pemeriksaan payudara sendiri (SADARI)

d. Melakukan praktik SADARI bersama siswi

e. Melakukan evaluasi terhadap deteksi dini kanker payudara pada remaja puteri

\section{METODE}

Pengabdian masyarakat dilakukan melalui aplikasi zoominar dan streaming youtube. Hal ini dilakukan karena tidak memungkinkan untuk melakukan promosi kesehatan secara langsung ditengah wabah COVID-19. Bentuk kegiatan pengabdian ini adalah dengan menggunakan metode ceramah dan diskusi. Sasaran kegiatan ini adalah semua remaja putri. Kegiatan ini dilakukan pada 30 Agustus 2020. Jadwal kegiatan dimulai dengan persiapan proposal, persiapan pelaksanaan yang meliputi persiapan materi penyuluhan, pemantapan materi penyuluhan, kelengkapan serta pendukung kegiatan.

Adapun materi yang diberikan meliputi definisi kanker payudara, penyebab kanker payudara, gejala dan tanda kanker payudara, pencegahan kanker payudara, SADARI (pemeriksaan payudara sendri), dan langkah-langkah pemeriksaan payudara sendiri. Alat yang digunakan dalam pelaksanaan kegiatan ini yaitu lapptop danperangkatnya. Untuk demonstrasi praktik pemeriksaan payudara sendiri penulis menggunakan video tutorial yang direkam di laboratorium kebidanan menggunakan pantom payudara. Dalam kegiatan ini juga dilakukan sesi tanya jawab dan diadakan pemberiandooprize sebagai cara untuk melakukan evaluasi terhadap kegiatan pengabdian masyarakat ini, beberapa pertanyaan telah disiapkan dengan hadiah berupa pulsa bagi peserta yang dapat menjawab pertanyaan dengan benar. 


\section{Journal of Community Engagement in Health}

http://jceh.org

https://doi.org/10.30994/jceh.v4i2.165

ISSN: 2620-3758 (print); 2620-3766 (online)

Vol. 4 No 2. Sep 2021. Page. 282-286

\section{HASIL DAN PEMBAHASAN}

Hasil kegiatan pengabdian masyarakat ini adalah memberikan penyuluhan berupa pengetahuan kepada remaja putri akan pentingnya melakukan SADARI (pemeriksaan payudara sendiri). Hal ini dilakukan sebagai upaya untuk mencegah terjadinya kanker payudara pada remaja puteri. Registrasi peserta untuk pendaftaran kegiatan pengabmas ini melalui lihttps://bit.ly/Kesproremaja. Kegiatan ini dihadiri oleh 309 peserta yang berada pada aplikasi zoominar maupun streaming youtube. Absensi kegiatan diambil menggunakan google form dengan link https://bit.ly/Linkabsensikesproremaja. Untuk streaming youtube melalui link https://youtu.be/phtU3TWpuJY. Penyuluhan sudah dilaksanakan dan berjalan dengan lancar dan baik dengan diikuti oleh para peserta remaja putri. Para peserta merasakan kegiatan ini sangat bermanfaat untuk mereka demi kesehatan diri sendiri. Peserta juga berharap kegiatan pengabdian masyarakat ini dapat dilakukan secara rutin. Hal ini terlihat dari beberapa pesan di kolom komentar pada aplikasi zoom saat pelaksaaan kegiatan berlangsung.

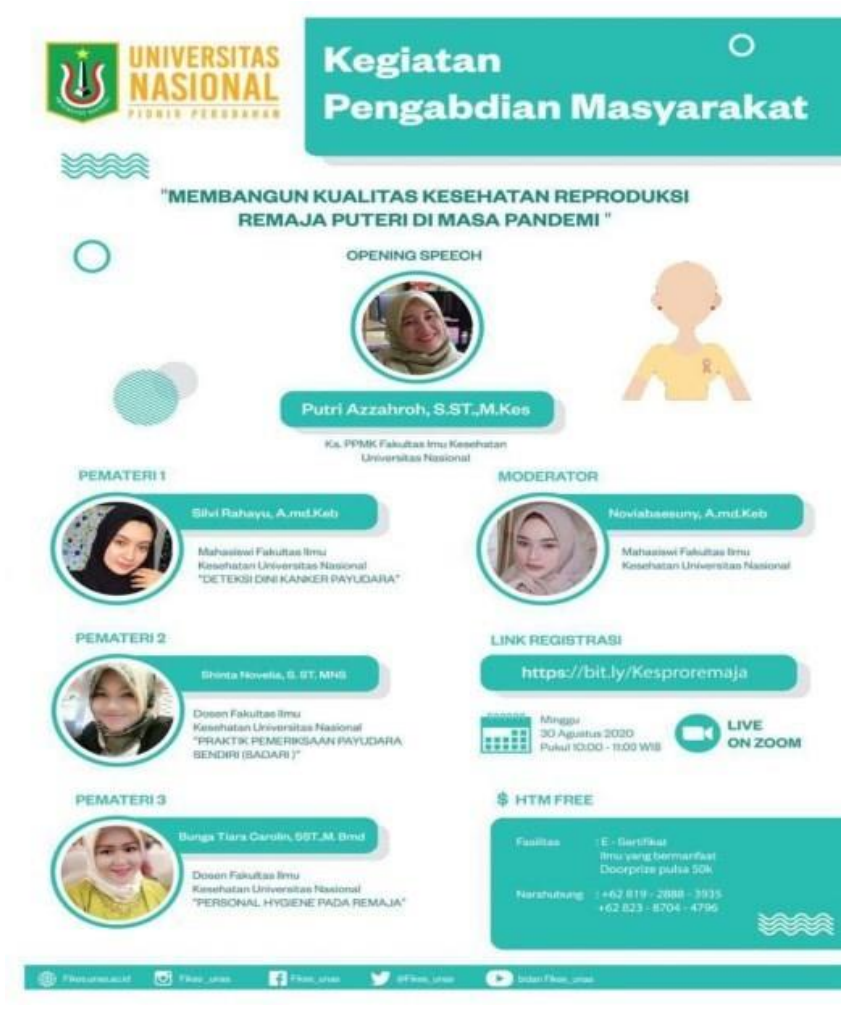

Gambar 1. Flyer kegiatan 


\section{Journal of Community Engagement in Health}

Z Zoominar: Membangun Kualitas Kes...

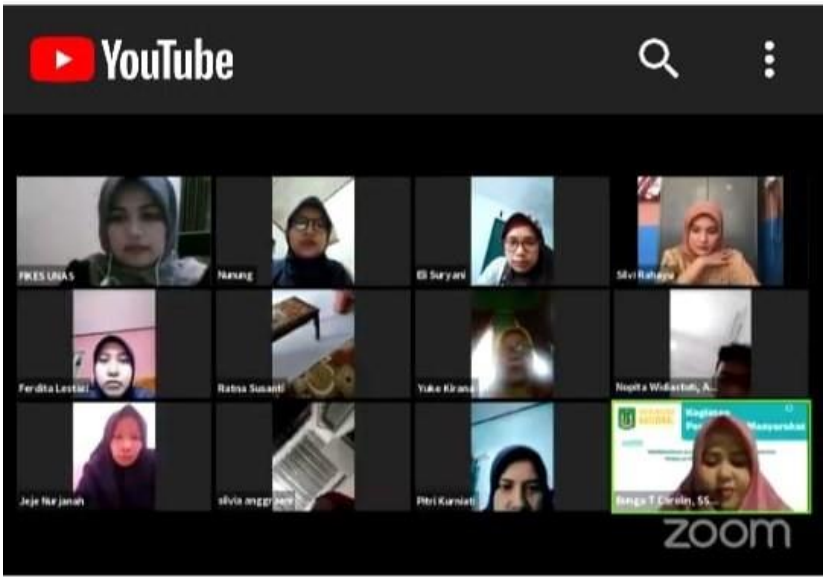

Zoominar: Membangun Kualitas

Kesehatan Reproduksi Remaja Puteri

di Masa Pandemi

Gambar 2. Streaming Youtube

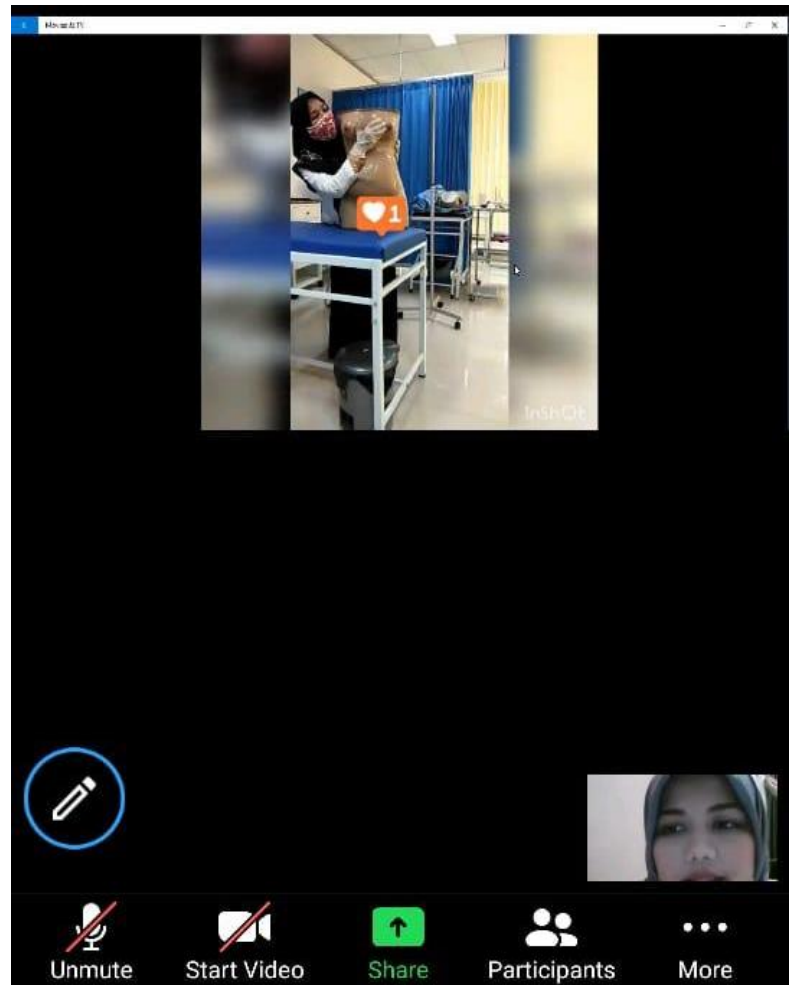

Gambar 3. Demonstrasi Praktik Pemeriksaan Payudara Sendiri (SADARI) 


\section{Journal of Community Engagement in Health}

http://jceh.org

ISSN: 2620-3758 (print); 2620-3766 (online)

https://doi.org/10.30994/jceh.v4i2.165

Vol. 4 No 2. Sep 2021. Page. 282-286

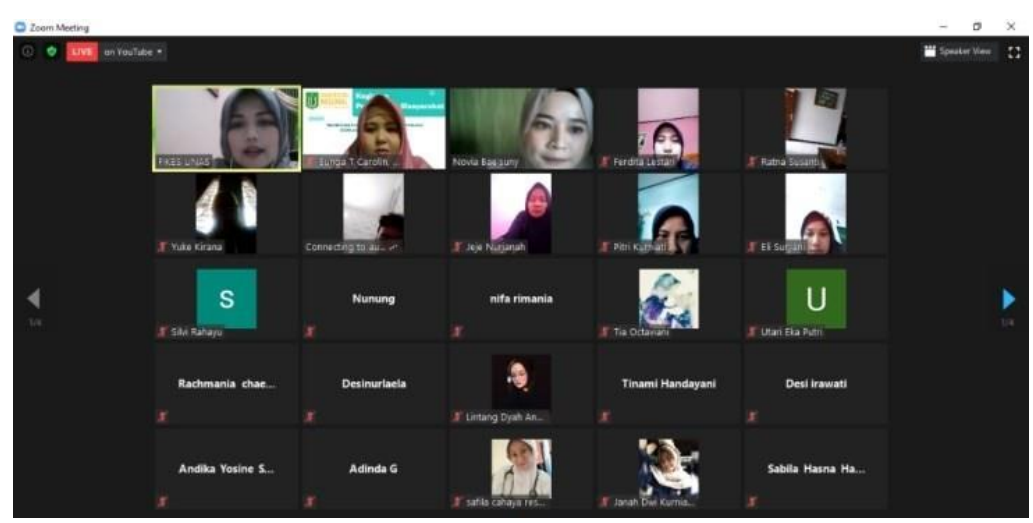

Gambar 4. Peserta Kegiatan

\section{KESIMPULAN}

Kegiatan pelatihan ini diselenggarkan dengan baik dan berjalan dengan lancar sesuai dengan rencana kegiatan yang telah disusun meskipun belum semua peserta menguasi materi yang diberikan, namun penulis sudah memberikan materi yang disajikan melalui email sehingga mereka dapat membaca ulang setelah kegiatan berakhir. Antusias peserta untuk mengetahui melakukan SADARI terlihat sesi diskusi serta dari pesan di kolom komentar. Adapun yang menjadi saran dalam kegiatan pengabdian masyarakat ini adalah diharapkan pengabdian masyarakat ini dapat berlanjut secara priodik dengan membahas materi-materi lain yang tentunya juga akan bermanfaat bagi remaja puteri.

\section{REFERENSI}

Anggorowati, L. (2013). Faktor risiko kanker payudara wanita. KEMAS: Jurnal Kesehatan Masyarakat, 8(2).

Angrainy, R. (2017). Hubungan pengetahuan, sikap tentang sadari dalam mendeteksi dini kanker payudara pada remaja. Jurnal Endurance: Kajian Ilmiah Problema Kesehatan, 2(2), 232-238.

Ekanita, P., \& Khosidah, A. (2013). Hubungan antara pengetahuan dan sikap WUS terhadap perilaku pemeriksaan payudara sendiri (SADARI). Bidan Prada: Jurnal Publikasi Kebidanan Akbid YLPP Purwokerto, 4(02).

Ferlay, J., Soerjomataram, I., Dikshit, R., Eser, S., Mathers, C., Rebelo, M., ... \& Bray, F. (2015). Cancer incidence and mortality worldwide: sources, methods and major patterns in GLOBOCAN 2012. International journal of cancer, 136(5), E359-E386.

Ikhwanudin, A. (2013). Perilaku Kesehatan Santri: (Studi Deskriptif Perilaku Pemeliharaan Kesehatan, Pencarian dan Penggunaan Sistem Kesehatan Dan Perilaku Kesehatan Lingkungan Di Pondok Pesantren Assalafi Al Fithrah, Surabaya). Jurnal Sosial dan Politik, 2(2), 3.

Manuaba, BG. (2017). Memahami Kesehatan Reproduksi Wanita. Jakarta; Ercon

Dewi, M. (2017). Sebaran Kanker di Indonesia, Riset Kesehatan Dasar 2007. Indonesian Journal of Cancer, 11(1), 1-8. 